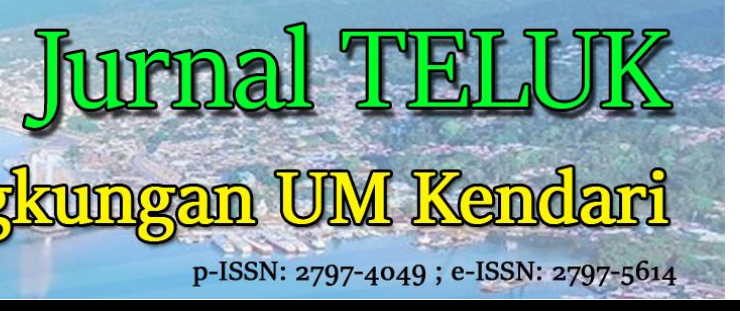

Artikel Penelitian

\title{
Pemanfaatan Kulit Buah Kakao sebagai Media Adsorpsi Logam Besi (Fe) dan Mangan (Mn) pada Air Sumur
}

\author{
Nurfahma ${ }^{a}$, Rosdiana $^{a}$, Aryani Adami $^{a}$ * \\ ${ }^{a}$ Program Studi Teknik Lingkungan, Fakultas Teknik, Universitas Muhammadiyah Kendari - Jl. K.H. Ahmad Dahlan No. 10, Kendari 93117 - Sulawesi \\ Tenggara, Indonesia.
}

\section{INFORMASI ARTIKEL}

Sejarah Artikel:

Diterima Redaksi: 2 Mei 2021

Revisi Akhir: 23 Mei 2021

Diterbitkan Online: 1 Juni 2021

\section{KATA KUNCI \\ Cocoa, Adsorption, Iron, Manganese, Carbon \\ KORESPONDENSI}

Telepon:

E-mail: aryaniadami@gmail.com

\begin{abstract}
A $\quad$ B $\quad \mathbf{S}$ T $\mathbf{R}$ A $\mathbf{C}$ T
This study aims to determine the percentage reduction in iron $\left(\mathrm{Fe}^{2+}\right)$ and manganese $\left(\mathrm{Mn}^{2+}\right)$ content in well water using carbon from cocoa peel as an adsorption media with media height variation. The results of this study indicate that well water sample contains iron $\left(\mathrm{Fe}^{2+}\right)$ levels of $1.39 \mathrm{mg} / \mathrm{L}$ and manganese $\left(\mathrm{Mn}^{2+}\right)$ of $0.76 \mathrm{mg} / \mathrm{L}$. After filtration with 60 minutes contact using carbon of cocoa peel as an adsorption media without activation, iron content and manganese content in well water decreased. The percentage reduction of iron $\left(\mathrm{Fe}^{2+}\right)$ content in media height $70 \mathrm{~cm}, 80 \mathrm{~cm}$ and $90 \mathrm{~cm}$ were $76.98 \%, 84.17 \%$ and $98.21 \%$. Meanwhile, the percentage in manganese $\left(\mathrm{Mn}^{2+}\right)$ content at $70 \mathrm{~cm}$ media height was $98,93 \%$ and archived an optimum reduction at $80 \mathrm{~cm}$ and 90 $\mathrm{cm}$ media height which is $99.79 \%$ with 60 minute contact time.
\end{abstract}

\section{PENDAHULUAN}

Kolaka Utara adalah salah satu kabupaten yang berada di Provinsi Sulawesi Tenggara sebagai penyangga perkebunan yang memiliki hasil buah kakao yang cukup tinggi. Hasil panen buah kakao pada tahun 2018 yakni 50.065,00 ton (BPS Kabupaten Kolaka Utara, 2019). Dengan produksi buah kakao yang tinggi tiap tahunnya akan menyebabkan produksi limbah kakao meningkat juga. Limbah buah kakao selalu ada, mengingat buah kakao pada perkebunan rakyat dapat dipanen sepanjang tahun.

Limbah buah kakao terbesar berasal dari kulitnya yakni sebesar $75 \%$. Kulit buah kakao yang dipisahkan dari bijinya merupakan hasil buangan yang tidak terpakai dan akan menumpuk seiring dengan semakin besarnya panen yang dilakukan serta dapat menimbulkan bau tak sedap. Selama ini pemanfaatan kulit buah kakao terbatas hanya untuk pakan ternak dan bahan baku pembuatan pupuk. Kulit buah kakao mengandung serat kasar 40,03\%, protein $9,7 \%$, selulosa $36,23 \%$, hemiselulosa 1,14\% dan lignin 20-27,95\% (Sianipar, dkk. 2016).

Kulit buah kakao dengan serat kasar yang tinggi dan kadar abu yang rendah serta sebagian besar terdiri dari selulosa dan lignin sangat cocok untuk pemanfaatan karbon. Karbon telah umum digunakan sebagai adsorben untuk mengadsorpsi gas dan senyawa-senyawa kimia tertentu atau sifat adsorpsinya selektif, salah satunya dapat dijadikan sebagai filter untuk meningkatkan kualitas air masyarakat.

Permasalahan kualitas air tanah sering dijumpai pada masyarakat, yakni kualitas air tanah yang digunakan kurang memenuhi syarat sebagai air bersih berdasarkan Peraturan Menteri Kesehatan Republik Indonesia Nomor 32 Tahun 2017 tentang Standar Baku Mutu Kesehatan Lingkungan dan Persyaratan Kesehatan Air untuk Keperluan Higiene Sanitasi. Salah satu parameter penting dalam air adalah logam berat antara lain besi dan mangan.

Kandungan besi dan mangan dalam air menyebabkan warna air berubah menjadi kuning kecoklatan setelah beberapa saat kontak dengan udara. Selain dapat mengganggu kesehatan dan menimbulkan bau yang kurang enak, kandungan besi dan mangan pada air juga menyebabkan warna kuning pada dinding bak serta bercak-bercak kuning pada pakaian (Erlani, 2011).

Penelitian yang dilakukan oleh Andryani (2013) yaitu pengaruh kombinasi ketebalan filter pasir dan arang tempurung kelapa terhadap penurunan kadar mangan air sumur. Persentase penurunan kadar mangan air sumur setelah melewati filter kombinasi pasir dan arang tempurung kelapa yang tertinggi pada 
ketebalan $60 \mathrm{~cm}$ adalah sebesar $82,5 \%$ sedangkan yang terendah pada ketebalan $40 \mathrm{~cm}$ adalah sebesar $55 \%$.

Hasil pengujian awal kandungan besi dan mangan pada air sampel awal menunjukkan bahwa air mengandung besi sebesar $1,39 \mathrm{mg} / \mathrm{L}$ dan mangan sebesar $0,76 \mathrm{mg} / \mathrm{L}$. Hal ini menunjukkan bahwa kandungan kadar besi dan mangan telah melebihi ambang batas maksimum yang diperbolehkan berdasarkan Peraturan Menteri Kesehatan Republik Indonesia Nomor 32 Tahun 2017 tentang Standar Baku Mutu Kesehatan Lingkungan dan Persyaratan Kesehatan Air untuk Keperluan Higiene Sanitasi.

\section{METODOLOGI}

\subsection{Tempat dan Waktu Penelitian}

Pembuatan media karbon dari kulit buah kakao dilakukan di Desa Kasumeeto, Kecamatan Pakue, Kabupaten Kolaka Utara. Penelitian dilakukan di Laboratorium Dasar Teknik Lingkungan Universitas Muhammadiyah Kendari dan analisis laboratorium dilaksanakan di UPTD Balai Laboratorium Kesehatan Daerah Provinsi Sulawesi Tenggara. Penelitian dilaksanakan dari awal pembuatan karbon hingga proses analisis data di laboratorium selama 3 bulan, yaitu pada bulan Desember 2020 sampai bulan Februari 2021.

\subsection{Populasi dan Sampel}

Populasi dalam penelitian ini adalah limbah kulit buah kakao yang berada di Kabupaten Kolaka Utara Provinsi Sulawesi Tenggara. Sedangkan sampel dari penelitian ini adalah air sumur gali yang mengandung kadar besi dan mangan yang cukup tinggi dan limbah kulit buah kakao.

\subsection{Prosedur Kerja}

Adapun prosedur kerja pada penelitian ini adalah:

\subsubsection{Pengambilan Sampel Air}

1) Dilakukan persiapan lapangan (survei) dengan menentukan lokasi titik pengambilan sampel air sumur gali

2) Wadah sampel air dibersihkan terlebih dahulu sebelum digunakan.

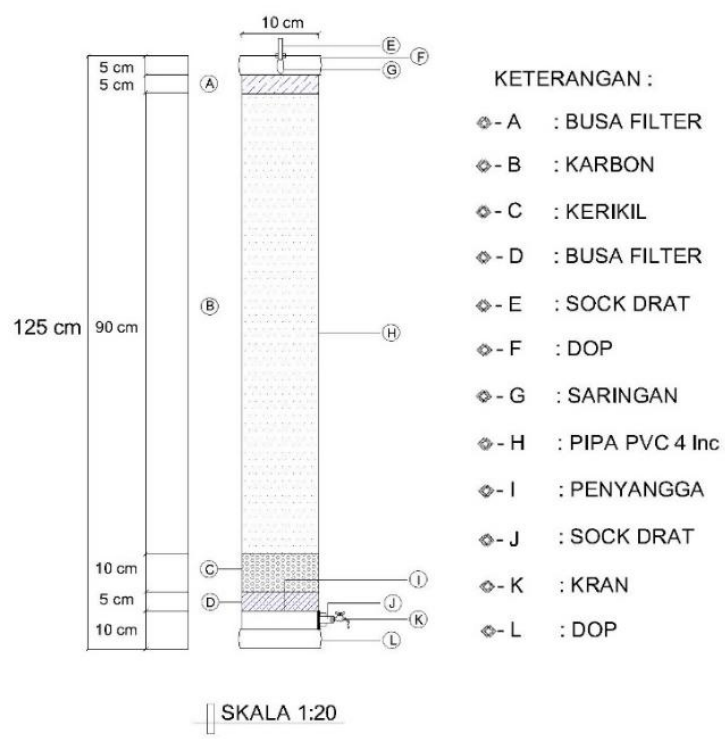

Gambar 1. Desain alat filtrasi
3) Dilakukan pengambilan sampel air dari salah satu sumur gali yang berada di Kelurahan Baruga Kecamatan Baruga Kota Kendari dengan menggunakan jerigen berkapasitas 20 liter.

4) Selanjutnya $600 \mathrm{ml}$ sampel air dibawa ke UPTD Balai Laboratorium Kesehatan Provinsi Sulawesi Tenggara untuk dilakukan pengujian awal besaran kadar Besi $(\mathrm{Fe})$ dan Mangan (Mn) sebelum dilakukan perlakuan.

\subsubsection{Proses Pembuatan Media Karbon Kulit Buah Kakao}

Proses pembuatan karbon kulit buah kakao ini dilakukan dengan cara karbonisasi. Adapun proses pembuatan karbon kulit buah kakao adalah sebagai berikut:

1) Limbah kulit buah kakao dibersihkan dari sisa-sisa kotoran menggunakan air bersih dan dipotong dengan ukuran 2-3 $\mathrm{mm}$.

2) Limbah kulit buah kakao dikeringkan dibawah sinar matahari selama 27 Jam.

3) Sampel kulit kakao yang telah kering dimasukkan ke dalam drum dan dibakar selama 60 menit.

4) Bara yang dihasilkan kemudian ditutup menggunakan daun pisang dan tanah dengan kondisi oksigen rendah selama 24 jam hingga menjadi arang.

5) Setelah menjadi arang, kemudian didinginkan pada suhu ruang $\left(20^{\circ} \mathrm{C}-25^{\circ} \mathrm{C}\right)$.

6) Arang kulit kakao yang telah dingin ditumbuk menggunakan alu dan diayak menggunakan ayakan 10 mesh.

\subsubsection{Proses Pembuatan Alat}

A. Rancangan Alat (Gambar 1)

1) Pipa PVC diameter 4 inci dipotong sepanjang $125 \mathrm{~cm}$.

2) Pada salah satu ujung pipa diberi lubang seukuran $1 / 2$ inci dengan jarak $5 \mathrm{~cm}$ dari ujung pipa.

3) Disiapkan penyangga untuk media filter dengan panjang 10 $\mathrm{cm}$ yang telah diberi lubang seukuran $1 / 2$ inci dengan jarak $5 \mathrm{~cm}$ dari ujung pipa.

4) Pasang penyangga pada pipa bagian bawah yang telah diberi lubang.

5) Beri seal tape pada sock drat luar.

6) Pasang sock drat luar yang dilengkapi dengan kran pada pipa yang telah diberi lubang

7) Pasang dop pada pipa bagian bawah dan bagian atas.

8) Kedua dop diberi lem menggunakan lem pipa.

\section{B. Tahap Filtrasi}

1) Media busa filter dan batu kerikil dengan tinggi $10 \mathrm{~cm}$ diisi ke dalam rangkaian alat.

2) Media karbon terlebih dahulu direndam selama 24 jam sebelum dimasukkan ke dalam alat filtrasi.

3) Media karbon kulit buah kakao dimasukkan ke dalam rangkaian alat dengan tinggi media $70 \mathrm{~cm}$.

4) Sampel air dimasukkan ke dalam alat penyaring sebanyak \pm 8 liter dengan waktu kontak selama 60 menit.

5) Keran air outlet dibuka dan air hasil adsorpsi ditampung dalam ember 15 menit hingga air dalam alat pengolahan habis.

6) Dilakukan hal yang sama untuk variasi ketinggian media 80 $\mathrm{cm}$ dan $90 \mathrm{~cm}$. 


\section{Uji Laboratorium Air Sampel Hasil Pengolahan}

1) Kandungan Besi ( $\mathrm{Fe}$ ) pada air hasil pengolahan diukur dengan menggunakan AAS.

2) Kandungan Mangan (Mn) pada air hasil pengolahan diukur dengan menggunakan AAS.

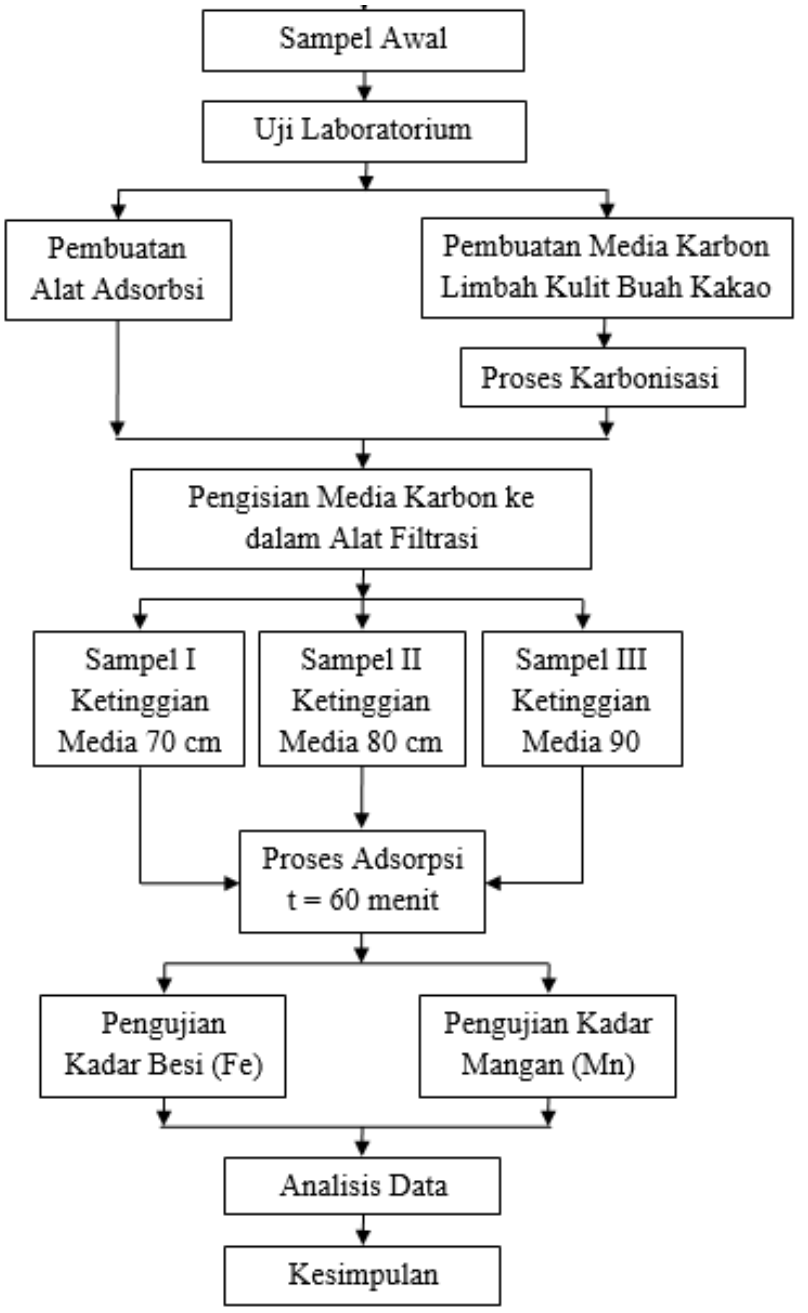

Gambar 2. Diagram alir penelitian

\section{HASIL DAN PEMBAHASAN}

Pada hasil penelitian ini dikemukakan mengenai berbagai temuan lapangan yang dilanjutkan dengan pembahasan dan analisa temuan lapangan. Temuan lapangan diperoleh melalui proses uji laboratorium terhadap kemampuan media karbon kulit buah kakao dalam menurunkan kadar besi dan mangan serta analisa data dilakukan dengan cara penyajian tabel dan grafik yang disertai dengan narasi.

\subsection{Preparasi Sampel}

Proses karbonisasi pada kulit buah kakao dilakukan dengan metode pembakaran langsung selama 60 menit di dalam drum. Kemudian bara yang dihasilkan dari proses pembakaran ditutup menggunakan daun pisang dan tanah dengan oksigen rendah hingga menghasilkan arang yang dibutuhkan untuk proses lebih lanjut. Limbah kulit buah kakao yang dikeringkan sebanyak 78 $\mathrm{kg}$ dan arang yang dihasilkan melalui proses karbonisasi sebanyak $4 \mathrm{~kg}$. Hasil karbonisasi limbah kulit buah kakao dapat dilihat pada Gambar 3.

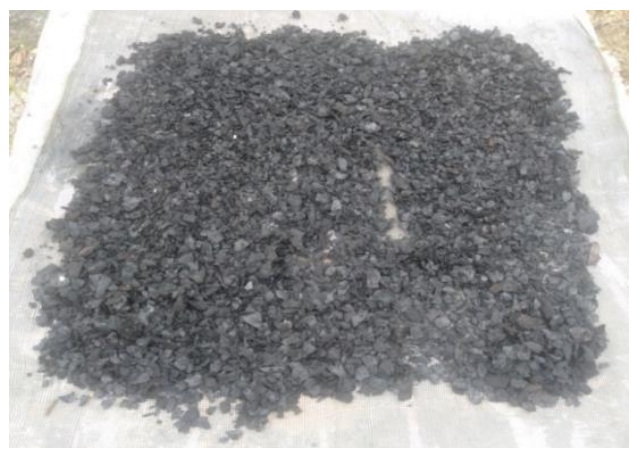

Gambar 3. Arang Kulit Buah Kakao

Arang dihaluskan dengan menggunakan alu. Hal ini berfungsi untuk menghaluskan dan memperkecil bentuk arang yang masih dalam bentuk dadu menjadi serbuk. Serbuk yang dihasilkan kemudian diayak menggunakan ayakan 10 mesh untuk menghasilkan ukuran partikel adsorben yang lebih kecil. Adsorpsi dengan karbon merupakan metode yang banyak digunakan untuk pemurnian air dan mengurangi kesadahan air karena strukturnya yang berpori dan mempunyai luas permukaan yang besar sehingga mempunyai kapasitas adsorpsi yang tinggi. Karbon dapat diproduksi dari bahan baku yang berasal dari hewan, tumbuhan limbah dan mineral yang mengandung karbon (Juwita dkk, 2018).

Proses karbonisasi menyebabkan dekomposisi material organik kulit kakao dan melepaskan zat yang mudah menguap. Sebagian besar unsur non karbon akan terlepas ke udara. Ruang yang ditinggalkan oleh unsur-unsur non karbon ini membentuk pori, hanya saja volume pori dan luas permukaan yang terbentuk biasanya masih kecil dibawah standar karbon aktif. Karbon kulit buah kakao yang telah dihasilkan dari proses karbonisasi selanjutnya diuji daya serapnya terhadap air sumur gali yang mengandung kadar besi dan mangan yang melebihi baku mutu sesuai dengan Peraturan Menteri Kesehatan Republik Indonesia No. 32 tahun 2017 tentang Standar Baku Mutu Kesehatan Lingkungan dan Persyaratan Kesehatan Air untuk Keperluan Higiene Sanitasi

\subsection{Hasil Adsorpsi Logam Fe dan Mn Air Sumur}

Sampel air diambil dari salah satu sumur gali di Kelurahan Baruga Kecamatan Baruga Kota Kendari. Sampel air kemudian dibawa ke UPTD Balai Laboratorium Daerah Provinsi Sulawesi Tenggara untuk mengetahui kandungan awal besi dan mangan pada air sampel. Hasil pengujian dapat dilihat pada Tabel 1.

Tabel 1. Hasil Uji Laboratorium Sampel Awal

\begin{tabular}{cccc}
\hline No. & Parameter & $\begin{array}{c}\text { Kadar } \\
(\mathbf{m g} / \mathbf{L})\end{array}$ & $\begin{array}{c}\text { Baku Mutu } \\
\text { Maksimum }(\mathbf{m g} / \mathbf{L})\end{array}$ \\
\hline 1 & Besi $(\mathrm{Fe})$ & 1,39 & 1,00 \\
2 & Mangan $(\mathrm{Mn})$ & 0,76 & 0,5 \\
\hline
\end{tabular}

Berdasarkan pengujian sampel awal di atas menunjukkan bahwa kadar besi dalam sampel air sebesar $1,39 \mathrm{mg} / \mathrm{L}$ dan kadar mangan dalam sampel air sebesar $0,76 \mathrm{mg} / \mathrm{L}$. Peraturan Menteri Kesehatan Republik Indonesia Nomor 32 Tahun 2017 tentang Standar Baku Mutu Kesehatan Lingkungan dan Persyaratan Kesehatan Air untuk Keperluan Higien Sanitasi dapat dilihat pada Gambar 4. Sampel air kemudian difiltrasi dengan menggunakan 
variasi ketinggian media filter karbon kulit buah kakao dengan tinggi media $70 \mathrm{~cm}, 80 \mathrm{~cm}$ dan $90 \mathrm{~cm}$. Hasil pengujian kadar besi dan mangan pada sampel air setelah melalui proses filtrasi dapat dilihat pada Tabel 2.

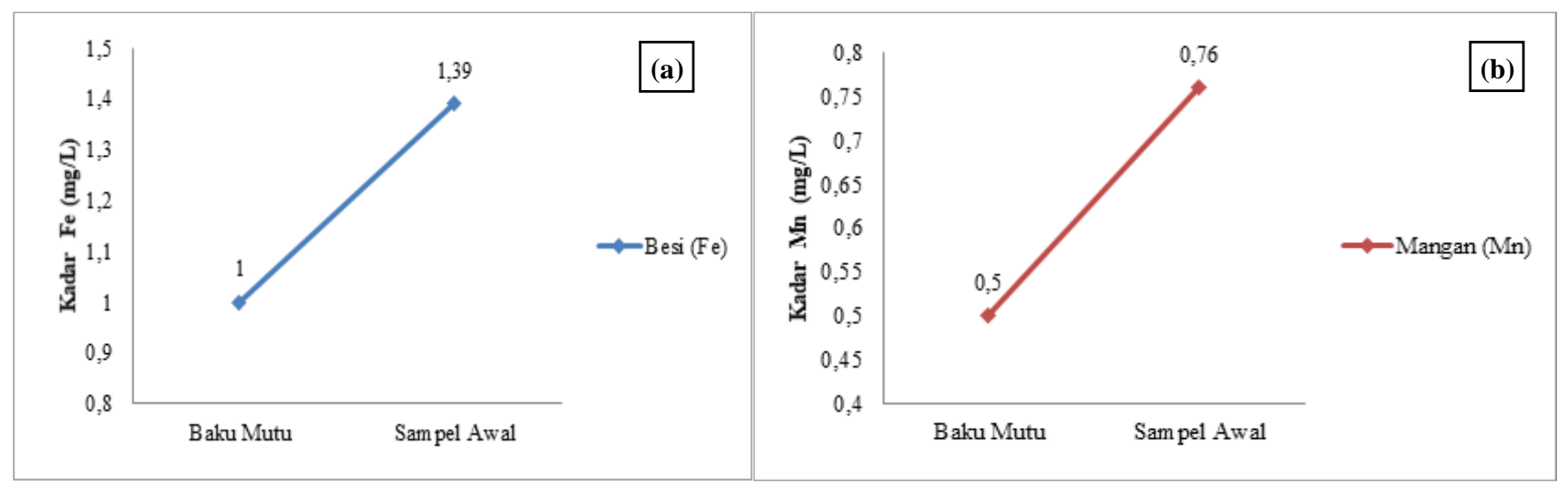

Gambar 4. (a) Penentuan kadar Fe dibandingkan dengan baku mutu (b) Penentuan kadar Mn dibandingkan dengan baku mutu

Tabel 2. Analisis Kadar Besi $\left(\mathrm{Fe}^{2+}\right)$ dan Mangan $\left(\mathrm{Mn}^{2+}\right)$ pada Sampel Air Sumur dengan Variasi Ketinggian Media Filter dengan Waktu Kontak Selama 60 Menit

\begin{tabular}{|c|c|c|c|c|c|c|c|c|c|c|}
\hline \multirow{3}{*}{$\begin{array}{l}\text { Parameter } \\
\text { Logam }\end{array}$} & \multirow{3}{*}{$\begin{array}{c}\text { Baku } \\
\text { Mutu } \\
(\mathrm{mg} / \mathrm{L})\end{array}$} & \multicolumn{3}{|c|}{ Sampel I } & \multicolumn{3}{|c|}{ Sampel II } & \multicolumn{3}{|c|}{ Sampel III } \\
\hline & & \multicolumn{3}{|c|}{$70 \mathrm{~cm}$} & \multicolumn{3}{|c|}{$80 \mathrm{~cm}$} & \multicolumn{3}{|c|}{$90 \mathrm{~cm}$} \\
\hline & & $\begin{array}{c}\text { Sebelum } \\
(\mathrm{mg} / \mathrm{L})\end{array}$ & $\begin{array}{c}\text { Sesudah } \\
(\mathrm{mg} / \mathrm{L})\end{array}$ & $\begin{array}{l}\text { Penurunan } \\
\text { Kadar }(\%)\end{array}$ & $\begin{array}{c}\text { Sebelum } \\
(\mathrm{mg} / \mathrm{L})\end{array}$ & $\begin{array}{c}\text { Sesudah } \\
\text { (mg/L) }\end{array}$ & $\begin{array}{l}\text { Penurunan } \\
\text { Kadar (\%) }\end{array}$ & $\begin{array}{c}\text { Sebelum } \\
(\mathrm{mg} / \mathrm{L})\end{array}$ & $\begin{array}{c}\text { Sesudah } \\
(\mathrm{mg} / \mathrm{L})\end{array}$ & $\begin{array}{l}\text { Penurunan } \\
\text { Kadar (\%) }\end{array}$ \\
\hline Besi (Fe) & 1,00 & 1,39 & 0,32 & 76,98 & 1,39 & 0,22 & 84,17 & 1,39 & 0,15 & 89,21 \\
\hline Mangan (Mn) & 0,5 & 0,76 & 0,0081 & 98,93 & 0,76 & $<0,0016$ & 99,79 & 0,76 & $<0,0016$ & 99,79 \\
\hline
\end{tabular}

Berdasarkan Tabel 2, hasil pengujian besi dan mangan pada air setelah proses filtrasi menunjukkan bahwa kandungan besi dan mangan pada sampel mengalami penurunan. Pada sampel I dengan ketinggian media $70 \mathrm{~cm}$, kadar besi dari $1,39 \mathrm{mg} / \mathrm{L}$ mengalami penurunan menjadi $0,32 \mathrm{mg} / \mathrm{L}$ dengan Persentase penurunan sebesar $76,98 \%$, dan kadar mangan dari $0,76 \mathrm{mg} / \mathrm{L}$ mengalami penurunan menjadi $0,0081 \mathrm{mg} / \mathrm{L}$ dengan persentase penurunan sebesar $98,93 \%$. Sampel II dengan ketinggian media $80 \mathrm{~cm}$, kadar besi mengalami penurunan dari 1,39 mg/L menjadi $0,22 \mathrm{mg} / \mathrm{L}$ dengan persentase penurunan sebesar $84,17 \%$, dan kadar mangan dari 0,76 mengalami penurunan menjadi $<0,0016$ $\mathrm{mg} / \mathrm{L}$ dengan persentase penurunan sebesar $99,79 \%$. Persentase penurunan kadar besi sebesar 89,21\% yaitu dari $1,39 \mathrm{mg} / \mathrm{L}$ menjadi $0,15 \mathrm{mg} / \mathrm{L}$, begitu pula dengan kadar mangan terjadi penurunan dengan persentase sebesar $89,21 \%$ yaitu dari $0,5 \mathrm{mg} / \mathrm{L}$ menjadi $<0,0016 \mathrm{mg} / \mathrm{L}$.

Hasil pengujian kadar besi pada air setelah proses filtrasi menunjukkan bahwa proses adsorpsi kadar besi dalam air bersih dengan menggunakan media kulit buah kakao yang telah dikarbonisasi terjadi dengan baik. Adapun perbandingan penurunan kadar besi sebelum dan sesudah dengan standar baku mutu kesehatan lingkungan dan persyaratan kesehatan air untuk keperluan higiene sanitasi dapat dilihat pada Gambar 5.

Berdasarkan standar baku mutu kesehatan lingkungan dan persyaratan kesehatan air untuk keperluan higiene sanitasi, maksimum kadar besi dalam air bersih adalah $1 \mathrm{mg} / \mathrm{L}$. Pada gambar 4.4 menunjukkan bahwa setelah dilakukan proses adsorpsi dengan variasi ketinggian media karbon kulit buah kakao, kadar besi mengalami penurunan. Pada sampel I dengan ketinggian media karbon $70 \mathrm{~cm}$, kadar besi mengalami penurunan dari $1,39 \mathrm{mg} / \mathrm{L}$ menjadi $0,32 \mathrm{mg} / \mathrm{L}$ dengan efisiensi penurunan sebesar $76,98 \%$.

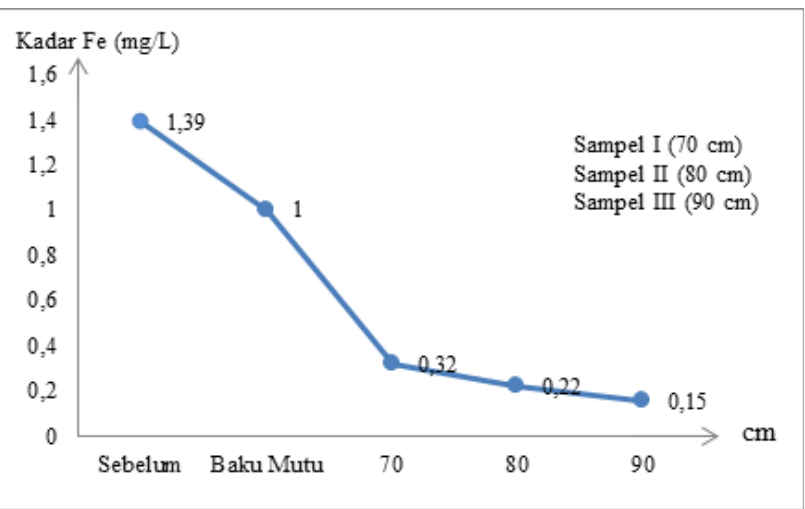

Gambar 5. Analisis Perbandingan Kadar Besi $\left(\mathrm{Fe}^{2+}\right)$ Sebelum dan Sesudah Pengolahan pada Sampel I Sampel II dan Sampel III

Pada ketinggian media karbon $80 \mathrm{~cm}$, kadar besi mengalami penurunan dari $1,39 \mathrm{mg} / \mathrm{L}$ menjadi $0,22 \mathrm{mg} / \mathrm{L}$ dengan efisiensi penurunan sebesar sebesar $84,17 \%$ dan pada ketinggian media karbon $90 \mathrm{~cm}$, kadar besi mengalami penurunan dari 1,39 $\mathrm{mg} / \mathrm{L}$ menjadi $0,15 \mathrm{mg} / \mathrm{L}$ dengan efisiensi penurunan sebesar $89,21 \%$. Penurunan kadar besi disebebkan oleh adanya kandungan lignin, selulosa, dan hemiselulosa dalam karbon kulit buah kakao. Zat tersebut berperan sebagai adsorben yang akan menyerap logam-logam berat dengan menyerap ion-ion bebas yang ada di dalam air termasuk kadar besi.

Hasil penelitian ini menunjukkan bahwa air bersih hasil perlakuan dengan media karbon kulit buah kakao dengan variasi beda ketinggian media karbon menghasilkan air bersih dengan kadar besi yang telah memenuhi standar baku mutu. Dari keterangan tersebut, dapat disimpulkan bahwa media adsorben kulit buah kakao yang telah dikarbonisasi mampu menurunkan kandungan logam besi dalam air. Berdasarkan penelitian sebelumnya yang dilakukan oleh Sianipar dkk. (2016), yang melakukan pengolahan media sebelum digunakan yaitu dengan 
proses fisika dan kimia. Pada penelitian tersebut, pembuatan arang aktif kulit buah kakao telah melalui tahap dehidrasi (penghilangan kadar air), karbonisasi (pengarangan) dimana pada proses pengarangan kulit buah kakao dilakukan pada suhu $600^{\circ} \mathrm{C}$ selama 1 jam yang kemudian dilakukan penghalusan yang menggunakan alu, dan mortar serta blender untuk memperkecil bentuk arang. Pada tahap berikutnya dilakukan proses aktivasi pada arang yang dilakukan dengan perendaman yang menggunakan aktivator bahan kimia yaitu asam klorida $(\mathrm{HCl})$.

Menurut Sianipar dkk. (2016), menggunakan variasi massa media yaitu dengan massa 2 gram memiliki nilai efisiensi penurunan sebesar $84,680 \%$, pada massa 2,5 gram memiliki nilai efisiensi penurunan sebesar $83,000 \%$ dan pada massa 3 gram memiliki niai efisiensi penurunan sebesar 82,000\%. Dari penelitian tersebut, diperoleh bahwa kemampuan adsorpsi tidak berbanding lurus dengan massa media. Hal ini karena saat massa adsorben 2,5 gram dan 3 gram mengalami penurunan dengan nilai efisiensi masing-masing adalah $83,000 \%$ dan $82,000 \%$. Perbedaan ini tidak terlalu jauh berbeda dikarenakan bahwa jumlah konsentrasi besi yang dapat diserap oleh adsorben hampir sama pada massa adsorben.

Penelitian ini menunjukkan bahwa semakin tinggi tumpukan media, maka semakin baik proses adsorpsi yang terjadi. Hal ini terjadi karena semakin meningkatnya jumlah adsorben maka luas permukaan adsorben lebih banyak tersedia sehingga semakin banyak zat besi yang teradsorpsi. Selain itu perbedaan perlakuan media ternyata menunjukkan hasil yang signifikan dimana karbon kulit buah kakao yang hanya melalui proses karbonisasi saja dapat menurunkan kadar besi. Pada ketinggian media $70 \mathrm{~cm}$ efisiensi penurunan kadar besi sebesar 76,98\% dimana nilai ini merupakan efisiensi penurunan terendah. Pada ketinggian $80 \mathrm{~cm}$ memiliki efisiensi penurunan sebesar 84,17\% dan pada ketinggian 90 memiliki efisiensi penurunan sebesar $89,21 \%$ dimana nilai ini merupaka nilai efisiensi penurunan paling besar.

Berdasarkan data tersebut dapat disimpulkan bahwa pada penelitian Sianipar dkk. (2016), yang menggunakan perlakuan dengan cara aktivasi media karbon dengan asam klorida $(\mathrm{HCl})$ menunjukkan bahwa hasil efisiensi penurunan kadar besi pada air sumur sebesar $84,680 \%$. Sementara pada penelitian ini yang menggunakan karbon tanpa perlakuan, menghasilkan nilai efisiensi penurunan kadar besi dalam air sangat besar yaitu sebesar $89,21 \%$. Besarnya efisiensi penurunan ini disebabkan karena pada penelitian ini jumlah adsorben yang digunakan lebih banyak dibandingkan dengan jumlah adsorben pada penelitian sebelumnya, sehingga efisiensi penurunan kadar besi pada penelitian ini lebih baik dari pada penelitian sebelumnya.

Penurunan kadar mangan (Mn) dalam air sampel setelah dilakukan proses adsorpsi menggunakan media kulit buah kakao yang telah dikarbonisasi dengan variasi ketinggian media adsorpsi. Adapun perbandingan penurunan kadar mangan sebelum dan sesudah pengolahan dengan baku mutu persyaratan kesehatan lingkungan dan persyaratan kesehatan air untuk keperluan higiene sanitasi dapat dilihat pada Gambar 6 .

Berdasarkan Gambar 6 menunjukkan bahwa kadar mangan dalam standar baku mutu air adalah $0.5 \mathrm{mg} / \mathrm{L}$ sedangkan pada sampel air, kadar mangan sebelum perlakuan adalah $0,76 \mathrm{mg} / \mathrm{L}$. Setelah dilakukan perlakuan dengan menggunakan media filter karbon kulit buah kakao dengan variasi ketinggian media, kadar mangan dalam air pada sampel I dengan ketinggian media $70 \mathrm{~cm}$ mengalami penurunan menjadi $0,0081 \mathrm{mg} / \mathrm{L}$ dengan efisiensi penurunan sebesar $98,93 \%$.

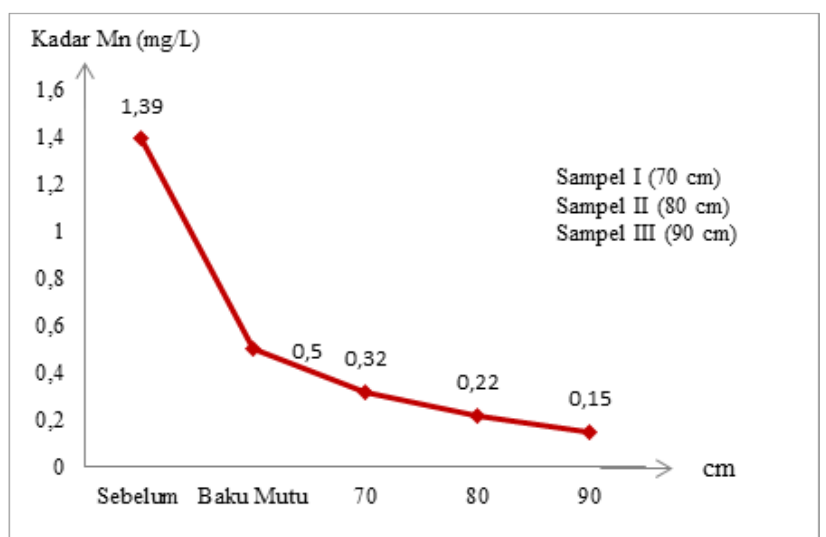

Gambar 6. Analisis Perbandingan Kadar Mangan $\left(\mathrm{Mn}^{2+}\right)$

Sebelum dan Sesudah pada Sampel I, Sampel II dan Sampel

Sedangkan pada sampel II dengan media ketinggian media $80 \mathrm{~cm}$ dan sampel III dengan ketinggian media $90 \mathrm{~cm}$, kadar mangan dalam air mengalami penurunan menjadi $<0.0016 \mathrm{mg} / \mathrm{L}$ dengan efisiensi penurunan sebesar 99,79\%. Hal ini dapat disimpulkan bahwa kadar mangan pada air sampel I, II dan III setelah perlakuan sudah memenuhi standar baku mutu air bersih. Penurunan kadar mangan terjadi karena kadar Mangan $\left(\mathrm{Mn}^{2+}\right)$ dalam air yang teroksidasi menjadi $\mathrm{Mn}^{3+}$ atau $\mathrm{Mn}^{5+}$ dan $\mathrm{Mn}^{7+}$ dalam keadaan bebas. Sehingga terjadi adsorbsi karbon kulit buah kakao terhadap kadar mangan yang cukup tinggi.

Kulit buah kakao mampu menurunkan kandungan mangan dalam air sumur dengan penggunaan variasi ketinggian media. Kemampuan adsorben dari kulit buah kakao untuk mengadsorpsi ion logam mangan disebabkan oleh penggunaan ketinggian media karbon kulit buah kakao terhadap proses adsorpsi. Hal ini menunjukkan bahwa semakin banyak jumlah adsorben yang digunakan untuk mengadsorpsi mangan maka semakin banyak pula mangan yang teradsorpsi. Penelitian ini sejalan dengan penelitian terdahulu Andryani (2013) yang telah melakukan penelitian terhadap penurunan kadar mangan pada air sumur dengan menggunakan kombinasi ketebalan media pasir dan arang tempurung kelapa dimana dilakukan pengulangan sebanyak 3 kali dalam waktu tinggal selama 5 menit, menunjukkan bahwa pada filter dengan ketinggian media $40 \mathrm{~cm}$ dengan persentase penurunan yang terendah yaitu sebesar $55 \%$, pada ketinggian 50 $\mathrm{cm}$ persentase penurunan sebesar $67,5 \%$ dan pada ketinggian 60 $\mathrm{cm}$ persentase penurunan sebesar $82,5 \%$.

Penelitian ini efisiensi penurunan kadar mangan menggunakan karbon kulit buah kakao dengan variasi ketinggian media dengan melakukan pengulangan sebanyak 3 kali dalam waktu tinggal 60 menit, menunjukkan bahwa persentase penurunan pada ketinggian media $70 \mathrm{~cm}$ yaitu sebesar $98,93 \%$ sedangkan pada ketinggian $80 \mathrm{~cm}$ dan $90 \mathrm{~cm}$ persentase penurunan kadar mangan sama yaitu sebesar 99,79\%. Hal ini terjadi akibat minimya kemampuan karbon kulit buah kakao yang diolah tanpa melalui proses aktivasi dalam menurunkan kadar mangan dalam air, sehingga media karbon menjadi cepat jenuh dan mengalami kesetimbangan, akibatnya kinerja penyerapan media karbon semakin berkurang. Penelitian ini menggunakan karbon kulit buah kakao tanpa melalui proses aktivasi sebagai media adsorben dalam menurunkan kadar mangan dalam air. Sehingga dapat disimpulkan bahwa penggunaan ketinggian 
media adsorben dapat mempengaruhi kadar mangan dalam air, hal ini disebabkan karena semakin banyak adsorben yang digunakan maka semakin besar penyerapan ion mangan dalam air.

\section{KESIMPULAN}

Karbon kulit buah kakao dengan proses karbonisasi mampu menurunkan kadar Besi $\left(\mathrm{Fe}^{2+}\right)$ dan Mangan $\left(\mathrm{Mn}^{2+}\right)$ dengan baik tanpa melalui proses aktivasi terlebih dahulu. Persentase penurunan kadar Besi $\left(\mathrm{Fe}^{2+}\right)$ dengan menggunakan variasi beda ketinggian media $70 \mathrm{~cm}, 80 \mathrm{~cm}$, dan $90 \mathrm{~cm}$ berturut-turut adalah $76,98 \%, 84,17 \%$, dan $89,21 \%$. Sementara persentase penurunan kadar Mangan $\left(\mathrm{Mn}^{2+}\right)$ pada ketinggian media $70 \mathrm{~cm}$ sebesar 98,93\% dan mencapai persentase penurunan optimum pada ketinggian media $80 \mathrm{~cm}$ dan $90 \mathrm{~cm}$ yaitu $99,79 \%$.

Penggunaan variasi beda ketinggian media dapat mempengaruhi penurunan kadar besi dan mangan dalam air sumur yang telah sesuai dengan Peraturan Menteri Kesehatan Republik Indonesia Nomor 32 Tahun 2017 tentang Standar Baku Mutu Kesehatan Lingkungan dan Persyaratan Kesehatan Air untuk Keperluan Higiene Sanitasi. Penurunan kadar besi dengan variasi ketinggian media $70 \mathrm{~cm}, 80 \mathrm{~cm}$ dan $90 \mathrm{~cm}$ berturut-turut adalah $0,32 \mathrm{mg} / \mathrm{L}, 0,22 \mathrm{mg} / \mathrm{L}$ dan $0,15 \mathrm{mg} / \mathrm{L}$ begitu pula dengan penurunan kadar mangan pada ketinggian media $70 \mathrm{~cm}$ sebesar $0,0081 \mathrm{mg} / \mathrm{L}$ dan mencapai penurunan optimum pada ketinggian media $80 \mathrm{~cm}$ dan $90 \mathrm{~cm}$ sebesar < 0,0016 mg/L. Hal ini menunjukkan bahwa semakin tinggi penggunaan media karbon kulit buah kakao, semakin baik pula penurunan kadar besi dan mangan dalam air..

\section{UCAPAN TERIMA KASIH}

Ucapan terima kasih kami sampaikan pada Program Studi Teknik Lingkungan atas pelaksanaan penelitian ini.

\section{DAFTAR PUSTAKA}

Andryani, B. E., 2013. Pengaruh Kombinasi Ketebalan Filter Pasir dan Arang Tempurung Kelapa terhadap Penurunan Kadar Mangan (Mn) Air Sumur" Program Studi Kesehatan Masyarakat Fakultas Ilmu Kesehatan. Universitas Muhammadiyah Surakarta.

Badan Pusat Statistik Kabupaten Kolaka Utara, 2019. Produksi Perkebunan Menurut Kecamatan dan Jenis Tanaman (Ton) Tahun 2017 dan 2018.

Erlani, 2011. Variasi Luas Wilayah Cascade Terhadap Penurunan Kadar Besi, Jurusan kesehatan Lingkungan Poltekes Makasar.

Juwita, A. I., Ilham A,. Musdalifah, Emmi B. dan Syahrul B., 2018. Efektivitas Penggunaan Arang Aktif Limbah Kulit Kakao (Theobroma Cacao L.) untuk Menurunkan Kesadahan, Salinitas dan Senyawa Organik Air. Vol. 4 (1), hal. 2.

Peraturan Menteri Kesehatan Republik Indonesia Nomor 32 Tahun 2017 Tentang Standar Baku Mutu Kesehatan Lingkungan dan Persyaratan Kesehatan Air untuk Keperluan Higien Sanitasi, Kolam Renang, Solus Per Aqua, dan Pemandian Umum.
Sianipar, L. D., Titin A. Z, dan Intan S., 2016. Adsorpsi Fe (II) dengan Arang Kulit Buah Kakao (Theobroma Cacao L.) Teraktivasi Asam Klorida. Vol 5 (2), hal. 50. 